\title{
A Review of Architectural and Structural Design Typologies of Multi-Storey Timber Buildings in Europe
}

\author{
Vesna Žegarac Leskovar (1) and Miroslav Premrov* \\ Faculty of Civil Engineering, Transportation Engineering and Architecture, University of Maribor, \\ Smetanova Ulica 17, 2000 Maribor, Slovenia; vesna.zegarac@um.si \\ * Correspondence: miroslav.premrov@um.si
}

Citation: Žegarac Leskovar, V.;

Premrov, M. A Review of

Architectural and Structural Design Typologies of Multi-Storey Timber Buildings in Europe. Forests 2021, 12, 757. https://doi.org/10.3390/ f12060757

Academic Editor: Samuel L. Zelinka

Received: 21 April 2021

Accepted: 15 May 2021

Published: 8 June 2021

Publisher's Note: MDPI stays neutral with regard to jurisdictional claims in published maps and institutional affiliations.

Copyright: (c) 2021 by the authors. Licensee MDPI, Basel, Switzerland. This article is an open access article distributed under the terms and conditions of the Creative Commons Attribution (CC BY) license (https:// creativecommons.org/licenses/by/ $4.0 /)$.

\begin{abstract}
Numerous countries across the globe have witnessed the recent decades' trend of multistorey timber buildings on the rise, owing to advances in engineering sciences and timber construction technologies. Despite the growth and numerous advantages of timber construction, the global scale of multi-storey timber construction is still relatively low compared to reinforced concrete and steel construction. One of the reasons for a lower share of high-rise timber buildings lies in the complexity of their design, where the architectural design, the selection of a suitable structural system, and the energy efficiency concept strongly depend on the specific features of the location, particularly climate conditions, wind exposure, and seismic hazard. The aforementioned shows the need for a comprehensive study on existing multi-storey timber buildings, which correspond to the boundary conditions in a certain environment, to determine the suitability of such a construction in view of its adjustment to local contexts. Apart from exposing the problems and advantages of such construction, the current paper provides a brief overview of high-rise timber buildings in Europe. Moreover, it addresses the complexity of the design approach to multi-storey timber buildings in general. The second part of the paper highlights the importance of synthesising the architectural, energy, and structural solutions through a detailed analysis of three selected case studies. The findings of the paper provide an expanded view of knowledge of the design of tall timber buildings, which can significantly contribute to a greater and better exploitation of the potential of timber construction in Europe and elsewhere.
\end{abstract}

Keywords: timber; buildings; high-rise; mid-rise; multi-storey; tall; design; architectural; structural; energy efficiency; adaptability; local context

\section{Introduction}

Numerous countries across the globe have witnessed the recent decades' trend of prefabricated buildings on the rise, with a significant increase in the construction of highrise timber buildings (HRTB) and multi-storey timber buildings (MSTB). The term "highrise buildings" in the context of timber buildings has not yet been standardised, since different studies employ different categorisations of the building height. Yet, "high-rise" buildings are mainly considered as such when surpassing 25 metres [1,2] or having more than ten storeys [3].

In this paper, we use the term "multi-storey" buildings to refer to buildings with four or more storeys, although it usually refers to any building with more than one storey.

The structural stability of MSTB is similar to that of buildings of comparable heights built in other building materials, owing to advances in the sciences of engineering and timber construction technologies. In parallel with its popularity in practice, the topic of multi-storey timber construction tends to be ever more discussed also in scientific literature. Most works highlight its ecological benefits in addition to certain technological economic advantages. Among the most frequently emphasised assets is that of timber being a renewable material, binding carbon during its growth. This leads to a lesser impact on the 
global warming potential when using timber in construction, as compared to other building materials [4-6]. Moreover, significant beneficial elements from the construction technology perspective encompass a high degree of prefabrication and construction speed [7] along with lower energy demand for transportation and assembly due to a lower weight of timber prefabricated components. Nonetheless, a number of scientific study authors point to certain risks arising from the growing trend of high-rise timber buildings, among which are seismic resistance [8], fire resistance [9,10], and acoustics [11,12]. In addition, they appeal for the introduction of sustainable forestry policies [13]. Apart from the mentioned strengths and weaknesses, media articles and scientific literature also bring to light achievements in the field of timber building heights, i.e., the number of storeys [14-17].

Despite the previously mentioned booming high-rise timber construction, tall timber buildings do not represent a contemporary innovation, as the first techniques of highrise timber structures originate from Japan and date back to the sixth century. Pagodas of Buddhist temples were of a significant height, such as the five-storey, 50-metre-high pagoda of the Kōfuku-ji Temple in Nara built in 725, or the ninth century Tō-ji Temple pagoda, whose five storeys were more than 57 metres high. There are also Europe-based cases, such as the 27-metre-high Norwegian Hopperstad Stave Church built in 1130, or the seven-storey Alter Bau, a 27-metre high granary in Germany, dating back to 1445 [14]. The modern era reduced the usage of timber to lower and auxiliary buildings, since it gradually became replaced by steel and concrete and was less often used for load-bearing structures.

As already stated, innovations and the updating of construction-related regulations encouraged a revival, and resulted in the expansion, of multi-storey timber construction A growing number of multi-storey buildings have been appearing particularly since 1995 [5] and a growing number of high-rise structures in the last decade $[2,14]$. Such intensity of progress accompanied by the growing trend of multi-storey timber construction opens a dilemma of milestones in the heights of timber buildings. Is pushing the limit of heights of timber buildings sensible and if so, to what extent and for which geographical or social areas?

According to certain forecasts, more than two thirds of the world population will presumably live in urban areas by 2050 [18]. High-rise construction in urbanised areas is therefore very sensible. Given the ecological benefits of timber as a load-bearing building material [4], it would be more rational to use timber than steel or concrete for such buildings. The aforementioned question regarding the sensibility of increasing the number of storeys in timber buildings is by no means unambiguous due to the described structural and fire loads. Therefore, it requires a holistic approach including all aspects of sustainable design and consideration of adaptability to local contexts.

The current study examines the prevalence and adaptability of the European MSTB stock to local contexts, taking into account the boundary conditions of different examined locations in Europe with the aim to expose its advantages, risks, and potentials.

\subsection{Literature Review}

Given the fact that multi-storey timber construction across the globe has been attracting ever more attention from designers, investors, and academics, there is a noticeable lack of effort made in the estimation of the existing construction techniques' usability [13] and adaptability to local specifics. Most of the existing scientific literature on multistorey timber buildings discusses energy [19], structural [20,21] or environmental problem scopes [6,22], or points out the potential of the use of timber as a sustainable building material and the significance of closer integration of various sectors, such as forestry, construction, energy, industry, and waste management [23]. On the other hand, there are almost no studies discussing the assessment of the suitability of such construction in a specific regional context. Among a few discussing adaptability to local contexts, the study of Goubran et al. [13] proposes diagnostic tools to assess the suitability of a location for the construction of high-rise timber buildings. The study adopts an approach based on the comprehensive consideration of sustainable principles. It allows the authors to define 
critical parameters associated with a specific geographical location and applicable to the assessment of the local suitability of high-rise timber construction. As opposed to the said study arising from a definition of parameters linked to a geographical area, the research of Kuzmanovska et al. [2] represents new emerging trends and topologies of high-rise timber buildings built after 2009 across the globe. The study systematically determines new emerging forms of high-rise timber architectural typologies that undergo a detailed systematisation according to chronology, construction location, and the building height, i.e., the number of storeys. The author further analyses the systematised groups from the aspects of structural properties, envelope systems, and architectural expression. Hence, the study provides a systematic review of the emerging global trends in the field of high-rise timber construction with stress on showing the evolution of emerging typology solutions. Interestingly, the study implies the general trend of the growing number of storeys in timber building worldwide, whose function has been gradually changing from residential to mixed use (flats and commercial-office space).

The architectural design of the newer generations of timber buildings shows more irregularity in the geometry of floor plans and envelopes, i.e., in the placement of the glazed non-load-bearing elements in the façade, affecting the structural building design [7]. The structural stability of multi-storey timber buildings is a crucial factor in the development of contemporary multi-storey construction. Therefore, it is sensible to benefit from the advantages of the established structural systems, such as the massive panel system presented in greater detail in the study of Žegarac Leskovar and Premrov [7] with basic load-bearing elements made of cross-laminated plate panel elements (CLT), and the frame-panel structural system, where the structural stability is based on composite action of timber linear frame elements and sheathing boards. Choosing appropriate sheathing thus largely depends on the number of storeys of the building in question and the consequent horizontal loads acting on wall elements, which must be able to sustain these loads [24]. When comparing only the horizontal and lateral/vertical load-bearing capacities, the massive-panel structural system generally demonstrates substantially higher values than the frame-panel system, which is why designers usually opt for CLT wall elements in planning buildings with more than three storeys. Most of the tallest timber buildings planned before 2009 were designed in the cross-laminated structural system [25]. This occurred despite the fact that the trend of constructing extremely high timber buildings has recently led to using mixed structural systems with the most frequent combination being that of cross-laminated and framed-wall structural systems [26]. Mixed structural systems can be used already at the placement of prefabricated wall elements with frame-panel wall elements installed on the building envelope to ensure better thermal insulation and with cross-laminated ones used for the interior wall elements to increase horizontal load-bearing capacity and stiffness. Certain prefabricated multi-storey timber buildings indicate reverse placement, where cross-laminated wall elements are placed on the building perimeter, while framed-wall structural elements are used as interior wall elements. Such a disposition is sensible, particularly in the case of mid-rise timber buildings. Due to their floor asymmetry, they are subject to high torsion loads acting on wall elements, which are highest on the building perimeter. Hence, it is more than obvious that a proper choice of the structural system depends to an equal extent on the number of storeys, architectural geometry, and the building location. Moreover, it requires a thoughtful analysis encompassing the aspects of load-bearing capacity and stiffness, thermal and sound insulation, as well as the economic aspect.

In addition to choosing a suitable architectural and structural design, energy efficiency and indoor environmental quality must be taken into account in the comprehensive quality assessment of high-rise timber buildings. Despite energy efficiency being a major topic for some time now, further intensive focus is expected to be put on energy efficient building design, particularly due to future climate scenarios. Therefore, the global reduction of energy needs for heating is expected, while the need for energy for cooling will increase, which may result in the overheating of buildings and less favourable thermal comfort. In the study of Dodoo and Gustavsson [27], the authors see the risk of overheating as slightly 
more present in buildings constructed in the massive timber structural system and less expressed in those built in the massive-panel structural system. Strategies to decrease the need for energy for cooling while reducing the overheating risk will become crucial in the future. Improved multi-storey timber building design will thus become a significant factor in optimising the energy efficiency of buildings.

Last but not least, sustainable design also includes, as an indispensable segment of modern design, environmental impact assessments of buildings [22]. They are directly related to the building architectural design, the selection of a structural system, and building materials, etc. [28]. Choosing the structural system itself, along with the height of the building and its location, affect the environmental performance of buildings [22]. Different structural systems and different building heights require different quantities of building materials, which has a subsequent impact on the environmental performance (LCA) of buildings [29]. The existing studies point to a certain inconsistency, as some of them assert that higher buildings have a poorer environmental performance $[29,30]$, while the others state that the environmental impact decreases with a higher number of storeys in timber buildings [28,31,32]. According to the listed studies, the assessment of environmental impact depends on the aforementioned factors and entails a comprehensive approach.

According to the quoted literature, the existing studies on the suitability of multistorey timber construction in a given climate region mainly discuss only individual aspects, ranging from architectural, energy performance, and environmental (LCA) to structural ones. With the current paper, we aim to fill the gap caused by non-existent studies, which would integrate and interlink all four of the above-listed aspects. The main contribution of the paper is its holistic approach combining a review of various diagnostic aspects of MSTB quality, with a certain degree of their co-dependent interaction.

\subsection{Aims of the Study}

Despite the increase and advantages shown by numerous studies in recent years, the global scale of multi-storey timber construction is still relatively low compared to massive reinforced concrete and steel construction. In addition to the aforementioned risks, this problem may be justified particularly with the complexity of high-rise timber building design, which has numerous limitations, particularly from the structural aspect. Design bases depend greatly on the specific features of the location, particularly climate conditions, wind exposure, and seismic hazard. Due to the complex design and the fact that the topic is relatively new, architects and constructors more often opt for other structural systems, with which they have more experience, when planning high-rise buildings. As a result, buildings that could be built from timber are still built from reinforced concrete or steel, which leads to poorer environmental performance than if this housing stock was built with timber. Last but not least, a lack of design practices, which could be the bases for certain guidelines to encourage designers to use more timber structural systems or decide on timber construction, is an even more pressing problem.

The aim of the paper is to review the state and point out the adaptability of European multi-storey timber construction to the geographical features of Europe. This requires a comprehensive approach with a synthesised selection of architectural, environmental, energy, and structural solutions, which will be addressed in the current paper on the interdisciplinary basis.

The contribution of the paper to science is in the presentation of important features of multi-storey timber buildings. These features must be discussed by architects, structural engineers, and other actors in the construction sector to select suitable solutions in the early stage of design with a long-term goal to produce more optimised and cost-effective methods of multi-storey timber construction to be used in daily practice.

It is important to point out that the aim of the paper is a detailed analysis of multistorey timber buildings constructed without any additional concrete or steel load-bearing structural core to increase the racking stability of buildings. Therefore, only pure timber structural systems with the load-bearing timber wall and floor elements are used in the 
presented analysis of specially selected case studies. The selected buildings meet the load-bearing structural requirements and have a low ecological impact caused by timber elements only.

\section{Prevalence of Multi-Storey Timber Buildings in Europe}

As mentioned previously, the technological development of timber products and their related technology enabled a significant increase in the construction of MSTB worldwide. In Europe, a high number of implemented MSTB projects can be seen, which is probably influenced by the fact that CLT technology, which is widely used in many MSTB, is well developed in Europe [3]. The definition for the division of MSTB by height adapted from Salvadori [3] is the following:

- low-rise buildings with one to three storeys;

- mid-rise buildings with four to ten storeys;

- high-rise buildings with more than ten storeys.

The categories of mid-rise and high-rise buildings are part of the category of multistorey timber buildings, denoting all buildings with four or more storeys.

In Europe, mid-rise timber buildings have been appearing since 2007, while high-rise timber buildings only started to appear after 2014. An overview of the European multistorey timber building stock based on chronological sequence and height is presented in Table 1.

Table 1. Overview of MSTB and HRTB in Europe—data adapted from [3] and [33].

\begin{tabular}{|c|c|c|c|c|c|}
\hline Name & Completed & Storeys & Height (m) & Location & $\begin{array}{c}\text { Type According } \\
\text { to Height }\end{array}$ \\
\hline E3 & 2007 & 7 & 25 & Berlin/GER & \multirow{25}{*}{ MSTB } \\
\hline Stadthaus & 2009 & 7 & 23 & London/UK & \\
\hline Limnologen & 2009 & $* * 1+7$ & / & Växjö/SWE & \\
\hline Bridport House & 2011 & 8 & 26 & London/UK & \\
\hline Holz8 & 2011 & 8 & 25 & Bad Aibling/GER & \\
\hline E3 & 2011 & 7 & / & Berlin/GER & \\
\hline Life Cycle Tower One & 2012 & 8 & 27 & Dornbirn/AT & \\
\hline Panorama Guistinelli & 2013 & 7 & 22 & Trieste/ITA & \\
\hline Maison de I'Iinde & 2013 & 7 & 23 & Paris/FRA & \\
\hline Wagramerstrasse & 2013 & 7 & 22 & Vienna/AT & \\
\hline Pentagon II & 2013 & 8 & 24 & Oslo/NO & \\
\hline Via Cenni Social Housing & 2013 & 9 & 27 & Milan/IT & \\
\hline Dalston Lane & 2013 & 9 & 32 & London/UK & \\
\hline Tamedia Office Building & 2013 & 7 & / & Zurich/CH & \\
\hline Edifici de Fusta Cavallers & 2014 & 6 & 20 & Lleida/SP & \\
\hline Kingsgate House & 2014 & 7 & / & London/UK & \\
\hline St. Dié-des-Vosges & 2014 & 8 & 27 & >St. Dié-des-Vosges/FRA & \\
\hline Strandparken & 2014 & 7 & 22 & Stockholm/SWE & \\
\hline Puukuokka & 2015 & 8 & 28 & Jyväskylä/FIN & \\
\hline Banyan Wharf & 2015 & 10 & 33 & London/UK & \\
\hline Trafalgar Place & 2015 & 10 & / & London/UK & \\
\hline Moholt 50/50 & 2016 & 9 & 31 & Trondheim/NO & \\
\hline UEA Blackdale Student Residences & 2016 & 7 & / & Norwich/UK & \\
\hline Dalston Lane & 2017 & $* * 1+9$ & 33.8 & London/UK & \\
\hline Sanctuary Ellerslie Road & 2018 & 7 & 30 & Glasgow/UK & \\
\hline Treet & 2014 & 14 & 52 & Bergen/NO & \multirow{6}{*}{ HRTB } \\
\hline Hoho Vienna Tower & 2020 & 24 & 84 & Vienna/AT & \\
\hline Mjøstårnet & 2019 & 18 & 85.4 & Brumunddal/NO & \\
\hline Silva & $2022 *$ & 18 & 50 & Bordeaux/FRA & \\
\hline Haut & 2021 * & 21 & 73 & Amsterdam/NL & \\
\hline Hypérion & $2021 *$ & 18 & 57 & Bordeaux/FRA & \\
\hline
\end{tabular}

* planned year of the conclusion of construction, ${ }^{* *} 1+\mathrm{x}=$ one storey in other structural system, $\mathrm{x}$ storeys in timber/no available data. 
Apart from the completed buildings presented in Table 1, there are a few high-rise timber buildings currently in the stage of design. They range from 57 to $76 \mathrm{~m}$ or have approximately 18 to 19 storeys, mainly planned to be built soon in Sweden and France $[3,33]$.

While the dominant structural strategy of buildings built up to 2013 was characterised by massive panel structural system with CLT load-bearing walls and slabs, the shift in the structural strategy is evident for the recently constructed buildings. To increase the building height, they are mostly constructed as hybrids of skeletal (post and beam) and massive panel (CLT slabs or walls) systems [2]. It is also evident in high-rise buildings that the concrete core is mostly used instead of CLT. Another shift is clear in façade systems with the steady decline of load-bearing façades for high-rise buildings, while the ratio of transparent façade areas increases with the increase of the building height [2].

\section{Main HRTB Design Parameters and Their Dependence on the Location Characteristics}

Contemporary timber construction currently highlights the ongoing global competition to reach greater building heights, asymmetrical geometries, more exposed timber, and larger shares of a transparent envelope. The architectural configuration of volumes and façades is distinctly connected to the structural strategy. The first timber buildings of the modern era were designed with a relatively regular geometry with the symmetrical and repeating floor plan if the vertical extension is considered. However, contemporary buildings show more geometry variations, such as irregular vertical extension generated by varying floor plates, the distortion of the basic structural grid, and the asymmetrical configuration of façade openings-windows and balconies [2]. The described elements of the building's architectural expression call for a series of technical and structural problems to be considered and solved. Another geometrical parameter influencing the structural stability of the building is the position of the structural core in relation to the building mass. Moreover, not only the structural issues, but also the energy efficiency and environmental performance are largely influenced by the building architectural design.

The concepts of the building design depend largely on the location's climatic conditions, i.e., solar exposure, temperature data, and wind exposure, in addition to the conditions determined by micro location, such as the influence of neighbouring buildings, the presence of vegetation, etc. Furthermore, the seismic hazard of specific locations is an important basis for the structural design.

In view of structural requirements brought on by increased horizontal loads (wind, earthquake) due to increased height and climate requirements that affect the environmental performance and the indoor environmental quality of a building, reasonable limitations regarding the height or the number of storeys of timber buildings in a certain environment must be determined.

The choice of the load-bearing structural system is a very important segment in the design of high-rise timber buildings. Vertical loads can generally be assumed by an independent resisting structural system. However, a combination of various structural systems has become increasingly popular recently to provide static stability when affected by horizontal loads (wind, earthquake). If a combination of the massive-panel and framepanel timber system (e.g., a seven-storey building called Limnologen in Sweden) can still be used to provide the static stability of mid-rise timber buildings, a combination of other structural systems or even different materials must be used in high-rise timber buildings (higher than ten storeys) [3]. Recently, designers have been increasingly using so-called hybrid structural systems to design the tallest timber buildings. On the one hand, such systems can favour the exclusive use of timber in a combination of various structural systems, e.g., a combination of a framed and massive-panel timber system (a 14-storey building called Treet in Bergen), in seismically less active areas. On the other hand, a combination of timber and another building material can be used particularly in the tallest buildings, which may significantly increase the horizontal stability of high-rise buildings, which will not be specially analysed in this study. 
Considering the problem from the aspect of seismic resistance, the study [8] shows that research of timber structural systems on shaking tables and comprehensive numerical simulations conducted in the last fifteen years have resulted in a higher number of mid-rise timber buildings even in seismic hazard zones. However, most high-rise timber buildings were still built in seismically less active areas (Figure 1), where wind loads are mainly decisive instead of earthquake loads as horizontal loads. Such is an example of a 14storey timber building called Treet in Bergen, which is a seismically less active area [34]. Figure 1 shows only mid-rise and high-rise timber buildings, in which the load-bearing structure against horizontal loads is almost fully made of timber, i.e., without any additional reinforced concrete $(\mathrm{RC})$ cores and similar reinforcements with other building materials. Recently, we have seen an increase in high-rise timber construction, where additional RC structural cores (e.g., 24-storey HoHo Tower Vienna) are used to provide horizontal stability, as timber structure could not independently assume all increased horizontal loads [2,35].

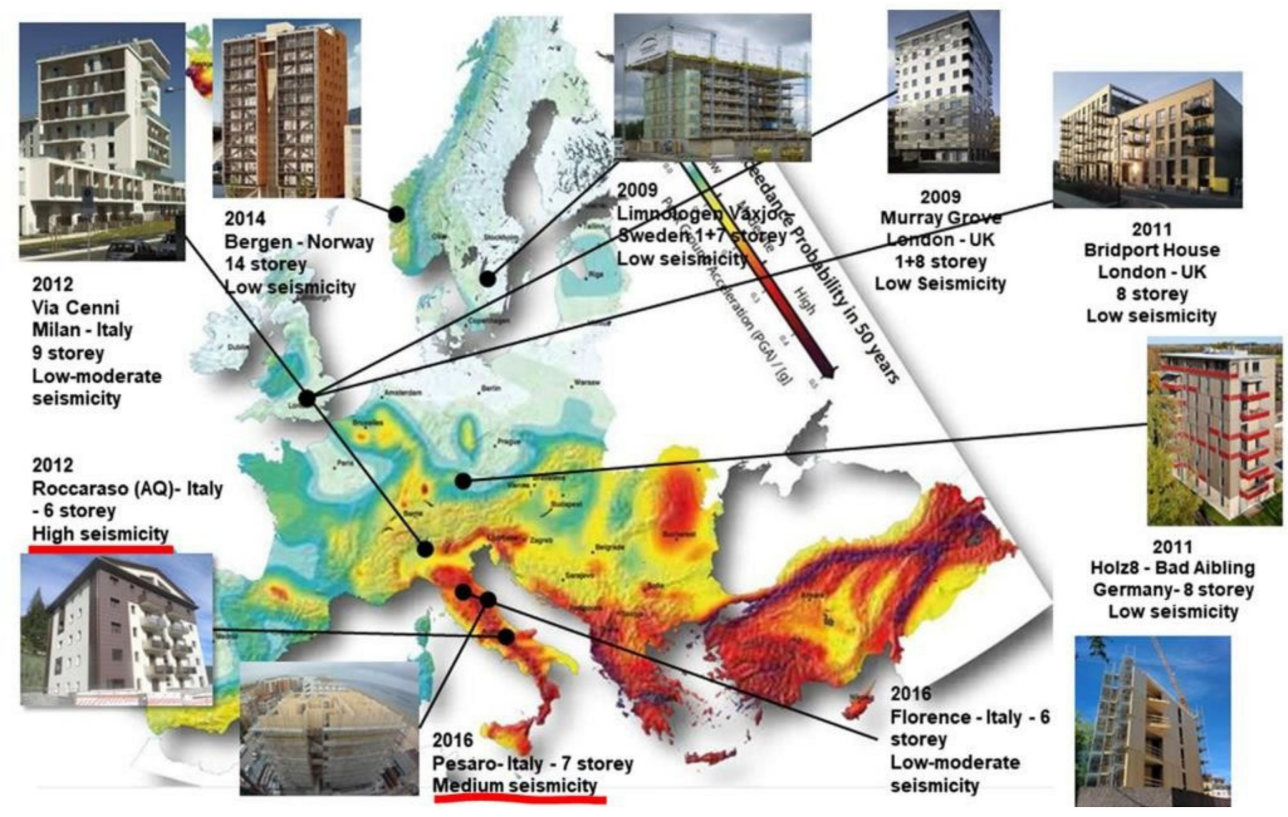

Figure 1. Multi-storey timber buildings built in the last fifteen years in European areas with different seismicity [8].

Attention is increasingly being paid to the design of so-called hybrid structural systems, in which timber as a primary material ensuring ecological excellence is combined with other building materials that are environmentally less friendly (reinforced concrete steel) but provide certain required structural reinforcements. In reference to the earthquake resistance design of timber buildings, the problem of inadequate guidelines in the current edition of Eurocode 8 [36] is particularly pointed out.

From the aspect of energy demands, however, the installation of larger south-oriented glazing areas has increased to utilise solar radiation. Installed glazing areas that are nonload-bearing in their planes in terms of assuming horizontal loads additionally aggravate the problem of the required horizontal load-bearing capacity. Due to the resulting asymmetric placement of load-bearing wall elements on the building envelope, in which only timber framed wall elements with traditional sheathing are deemed load-bearing against horizontal loads, torsion occurs in individual storeys of the building due to earthquake load. Transparent timber-glass wall elements have not been considered as load-bearing in their planes for horizontal load and are not considered by standards such as Eurocode 5 [37] as load-bearing cross bracing elements in their planes. The last decade has seen numerous studies and projects, in which timber-glass wall elements have been systematically developed and tested as load-bearing for horizontal loads [38-40]. The results showed a relatively low proportion of horizontal stiffness as compared to traditional frame-panel 
wall elements. For this reason, special 'double-skin' façade (DSF) timber elements were developed as part of the Home+ development project [41,42], in which a three-layer thermally insulating glazing was installed on the interior side of a timber frame and additionally tempered single-layer glass on the exterior side. As compared to previously developed timber-glass elements, such DSF elements showed higher horizontal load-bearing capacity and stiffness and should be sensibly included in the design of multi-storey timber buildings, particularly in lower storeys. In mid-rise timber buildings, DSF elements could enable designers to produce irregular floor plans.

An additional problem pointed out by authors in their publications [5,43] is the inconsistency of national regulations (rules, technical requirements, and standards) relative to timber building construction. Regulation provisions, particularly those referring to fire safety, partly hindered growth in multi-storey timber construction in the past.

It must be emphasised, however, that the final structural design of a building additionally depends on its micro-location and height, as it is generally known that wind loads exponentially increase only from a certain height of a building upwards, while earthquake loads increase almost linearly with the height of a building as schematically shown in Figure 2 for cases when higher loads are caused by earthquake loads.
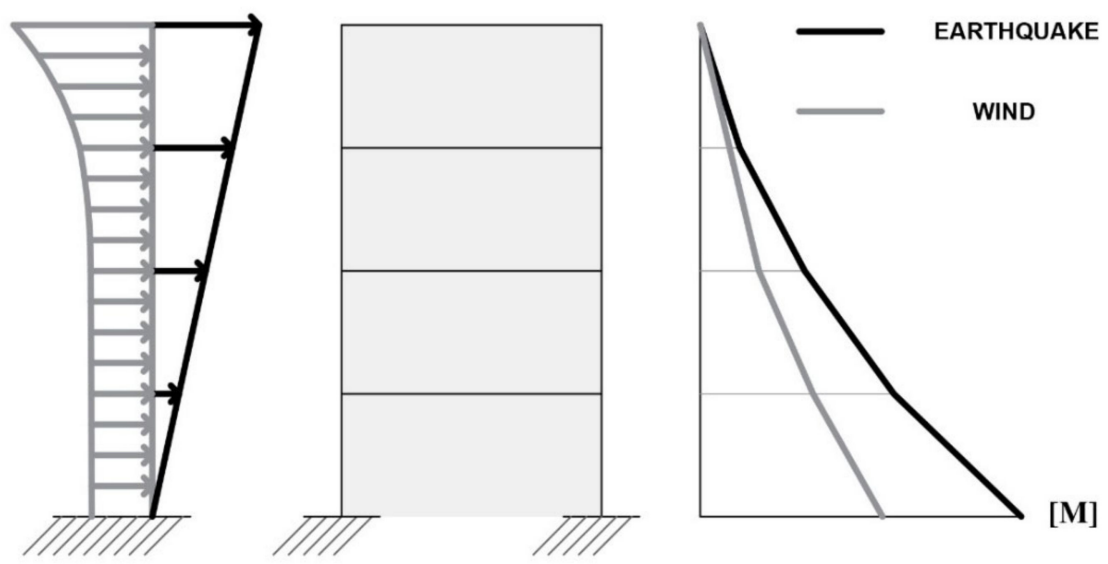

Figure 2. Display of how wind and earthquake load increases with the height of a building at a certain location.

Nonetheless, to uniformly distribute horizontal actions to the vertical bracing elements and satisfy the prescribed Eurocode 8 [36] conditions, it is of the utmost importance to take into account the concepts of rigid horizontal structural diaphragms. In this sense, the selection of the floor type must meet the conditions for the flexural and horizontal resistance of building platforms. Selecting the type of prefabricated floor element (cross-laminated or timber-frame) primarily depends on the floor span and the imposed load on a building according to the category of use, acting on the floor element in a storey. In residential buildings, where floor spans exceed six metres, the usual choice is cross-laminated (CLT) floor elements, whose price category is rather high [44].

In view of the latter and in order to simultaneously meet various criteria, i.e., structural (load-bearing capacity, stiffness, fire resistance) and building physics criteria (thermal and sound insulation), hybrid timber structural systems have been more frequently used, with one structural timber system applied to floor elements and another to wall elements, depending on the floor span, and the use, height, and location of the building [26]. Hybrid timber structural systems can be used already during the placement of prefabricated wall elements, with framed-wall structural elements installed on the building perimeter to ensure better thermal insulation and with cross-laminated ones used for interior wall elements to increase horizontal load-bearing capacity and stiffness. This disposition is sensible particularly in tall timber buildings. Due to their floor asymmetry, they are subject to high torsion loads acting on wall elements, with the highest impact exerted on the building perimeter. Hence, it is more than obvious that a proper choice of the structural 
system depends to an equal extent on the number of storeys, architectural geometry, and the building location. Moreover, it requires a thoughtful analysis encompassing the aspects of load-bearing capacity and stiffness and thermal and sound insulation, along with the economic perspective.

Last but not least, each building is unique. To adapt to local contexts, the primary concept of the architectural design must be further thoroughly calculated in terms of energy and structure in view of the selected micro-location.

\section{Analysis of the Selected HRTB Projects}

The survey encompasses 32 multi-storey timber buildings in Europe (Table 1) in the period from 2007 to 2021. From this set presented in Section 2, three projects were selected for the purposes of a detailed analysis. The selected MSTB are constructed exclusively with timber load-bearing structural elements. Another point is that they are built in different time periods and located in different climatic areas, presenting specific boundary conditions related to energy efficiency and structural requirements.

Limnologen complex (V̈̈xjö): The eight-storey timber building (from eight storeys above the ground, one storey in concrete and seven storeys in timber) was selected as the highest timber buildings in Sweden built at that time. It is the oldest of all three selected case studies, which might be reflected in architectural expression and the energy efficiency concept. It is very important from the structural point of view that the floor plan design of this buildings is asymmetric. Consequently, slight important torsional actions can apply primarily to envelope wall elements due to the wind load impact. Therefore, a combination of massive-panel (CLT) wall elements as envelope structural elements and timber-framed elements for internal walls is used to withstand the horizontal load impact. Additionally, the climate in Växjö with cold winters and mild summers preconditions the building design aiming at minimising heat losses.

Via Cenni social housing (Milan): The nine-storey timber building was chosen as a demonstration case of the highest CLT building in the world constructed in an active seismic area. Consequently, the structural limitations caused by a relatively high seismic impact will be described and analysed in combination with possible architectural and energy aspects. Since it was built in 2013, its architectural expression is expected to reflect a more contemporary design. From the energy efficiency aspect, the moderately continental climate of Milan requires not only minimal heat losses in the heating season, but also the thoughtful prevention of overheating in summer.

Treet building (Bergen): The 14-storey timber building was selected as the highest timber building in the world at that time. It is constructed fully with timber load-bearing elements. From the chronological perspective, it is also the newest among the three selected case studies, which is reflected in its height, façade design, etc. It should be emphasised that the building is located in an area with a low seismic activity. The problem is further discussed for structural limitations, which would appear if the earthquake became a decisive horizontal load instead of wind. Similarly to the Limnologen case, the Treet building is located in a cold climate region with cold and rainy winters, and cool summers, which sets specific boundary conditions for an effective energy efficient building design.

The described buildings are purpose-selected for limit cases when the load-bearing structure for both vertical and horizontal loads is exclusively wooden, i.e., without any other reinforcements with steel skeletons or reinforced-concrete structural cores. Such strengthening solutions are widely used in the highest timber structures in the world today, as described in Section 2. The Via Cenni social housing case has also been chosen, since the seismic load can be the decisive horizontal load (greater than the wind), which somehow directs the necessary simpler and symmetrical floor plan.

On the contrary, the Limnologen example can demonstrate the importance of hybrid timber construction systems, i.e., frame-panel and massive-panel, in asymmetrical floor plans, where there is a subsequent contradiction in the selection of thermal envelope wall elements from the viewpoints of structural stability and energy efficiency. The massive 
panel wall elements meet the structural requirements, while from the energy point of view, frame-panel elements would be much more appropriate.

All the selected cases are further analysed in depth from the architectural, energy, and structural perspectives, which points out the importance of the comprehensive design consideration of the tallest timber buildings in Europe constructed in different climatic conditions. It would be very beneficial to make the environmental comparison as well, which was, unfortunately, not conducted due to a lack of data. At the same time, it is important to have timber as the only structural material to withstand all load actions as the basic boundary condition, which can significantly improve the environmental impact of such solutions.

Table 2 lists all significant design parameters that will be further analysed for all three selected buildings. In addition to the location-dependent boundary conditions and the main architectural characteristics of buildings, the energy performance indicators are stated. For the structural part of the analysis, the maximal height of building $\left(H_{\max }\right)$, the number of storeys above the ground line $(n)$, and the number of storeys built in timber structural system only $\left(n_{t}\right)$ must also be presented. Because all three buildings are primarily residential buildings, the vertical live load acting on prefabricated floor elements is generally constant and in accordance with the Eurocode 1 standard [45] prescribed as $q=2 \mathrm{kN} / \mathrm{m}^{2}$. Therefore, only the horizontal load impact is especially presented in the table. As the wind load according to Eurocode 1 [45] depends on the maximal height of a building $\left(H_{\max }\right)$, as schematically presented in Figure 2 , the reference mean (basic) wind velocity pressure $\left(q_{b}\right)$ and the peak velocity pressure $\left(q_{p}\right)$ are alternatively presented if they are not both available from the data in the projects. The seismic action is presented in terms of ground design acceleration on type A ground $\left(a_{g, 475}\right)$. Finally, the type of resisting structural elements is presented separately for prefabricated floor and wall elements. Finally, fire resistance in terms of minutes (REI) is also presented.

Table 2. Main boundary conditions and properties of the selected projects under analysis.

\begin{tabular}{|c|c|c|c|}
\hline & Limnologen Buildings & Via Cenni Social Housing & Treet Building \\
\hline Location & Växjö, Sweden & Milan, Italy & Bergen, Norway \\
\hline Year of construction & 2009 & 2013 & 2015 \\
\hline Latitude/Longitude & $56^{\circ} 52^{\prime} 39^{\prime \prime} \mathrm{N} / 14^{\circ} 48^{\prime} 32^{\prime \prime} \mathrm{E}$ & $45^{\circ} 27^{\prime} 51^{\prime \prime} \mathrm{N} / 9^{\circ} 11^{\prime} 22^{\prime \prime} \mathrm{E}$ & $60^{\circ} 23^{\prime} 22^{\prime \prime} \mathrm{N} / 5^{\circ} 19^{\prime} 48^{\prime \prime} \mathrm{E}$ \\
\hline Climate & $\begin{array}{l}\text { Dfb humid continental Cfb } \\
\text { oceanic }\end{array}$ & Cfa, Humid subtropical & $\mathrm{Cfb}$ oceanic \\
\hline Wind load & $\begin{array}{c}v_{b, 0}=25 \mathrm{~m} / \mathrm{s} \\
q_{b}=0.39 \mathrm{kN} / \mathrm{m}^{2}\end{array}$ & $\begin{array}{c}v_{b, 0}=25 \mathrm{~m} / \mathrm{s} \\
q_{b}=0.39 \mathrm{kN} / \mathrm{m}^{2}\end{array}$ & $\begin{array}{c}v_{m}=44.8 \mathrm{~m} / \mathrm{s} \\
q_{p}=1.26 \mathrm{kN} / \mathrm{m}^{2}\end{array}$ \\
\hline Seismic zone $\left(a_{g, 475}\right)$ & $0.20 \mathrm{~m} / \mathrm{s}^{2}$ (very low) & $1.201 \mathrm{~m} / \mathrm{s}^{2}$ (moderate) & $0.90 \mathrm{~m} / \mathrm{s}^{2}$ (moderate) \\
\hline Max. height $\left(\mathrm{H}_{\max }\right)$ & No available data & $27 \mathrm{~m}^{*}$ & $52.8 \mathrm{~m}$ \\
\hline Number of storeys (n) & 8 above ground & 1 (garage floor) +9 above ground & 1 (garage floor) +14 above ground \\
\hline $\begin{array}{l}\text { Number of storeys in timber only } \\
\qquad\left(\mathrm{n}_{\mathrm{t}}\right)\end{array}$ & 7 & 9 & 14 \\
\hline Programme & Residential & Residential & Residential \\
\hline Shape & Lamella—dynamic shape & $\begin{array}{c}\text { High towers }+ \\
\text { lamella connecting buildings }\end{array}$ & Towers-compact shape \\
\hline Number of buildings & 4 & 4 & 1 \\
\hline Floor plan geometry & Asymmetrical lammela & Quite symmetrical & Symmetrical \\
\hline Vertical geometry & Repetitive floor plans & $\begin{array}{l}\text { Repetitive load-bearing structure, } \\
\text { slight variation of floor plans }\end{array}$ & $\begin{array}{l}\text { Repetitive modular dimensions, } \\
\text { variation of floor plans }\end{array}$ \\
\hline Structural cores & 2 cores & 1 centrally positioned core & $\begin{array}{c}1 \text { main centrally positioned core, } \\
1 \text { secondary core }\end{array}$ \\
\hline Façade design & SE façade with balconies & $\begin{array}{l}\text { Asymmetrically positioned } \\
\text { loggias }\end{array}$ & $\begin{array}{c}\mathrm{N} \text { and } \mathrm{S} \text { façade with fully glazed } \\
\text { balconies }\end{array}$ \\
\hline
\end{tabular}


Table 2. Cont.

\begin{tabular}{|c|c|c|c|}
\hline & Limnologen Buildings & Via Cenni Social Housing & Treet Building \\
\hline No. of apartments & 134 & 124 & 62 \\
\hline Apartment size & $34-114 \mathrm{~m}^{2}$ & $50-100 \mathrm{~m}^{2}$ & $43-66 \mathrm{~m}^{2}$ \\
\hline $\begin{array}{l}\text { Structural system } \\
\text { Wall elements }\end{array}$ & $\begin{array}{ll}\text { - } & \text { Exterior walls: 3-layer CLT } \\
\text { Interior apartment } \\
\text { separating walls: } \\
\text { timber-framed } \\
\text { Interior walls within } \\
\text { apartments: massive panel } \\
\text { (3-layer CLT) }\end{array}$ & $\begin{array}{l}\text { 5-layer CLT with variable } \\
\text { thickness from } 120 \mathrm{~mm} \text { (9th level) } \\
\text { to } 200 \mathrm{~mm} \text { (1st level) }\end{array}$ & $\begin{array}{l}\text { Glue-laminated (GL) } \\
\text { elements in truss (skeletal) } \\
\text { load-bearing system } \\
\text { CLT core (vertical resisting } \\
\text { only) }\end{array}$ \\
\hline Bracing system & $\begin{array}{l}\text { Exterior CLT walls and } \\
\text { timber-framed apartment } \\
\text { separating walls }\end{array}$ & All 5-layer CLT elements & Truss GL elements \\
\hline \multirow[t]{2}{*}{$\begin{array}{l}\text { Structural system } \\
\text { Floor elements }\end{array}$} & $\begin{array}{l}\text { 3-layer CLT slab strengthened by } \\
\text { T-shaped glulam beams (GL } 40 \mathrm{~h} \text { ) } \\
\text { at a distance of } 600 \mathrm{~mm}\end{array}$ & $\begin{array}{l}\text { 5-layer } 200 \mathrm{~mm} \text { CLT for } \\
\text { spans }<5.8 \mathrm{~m} \\
\text { 7-layer } 230 \mathrm{~mm} \text { CLT for } \\
\text { spans }<6.7 \mathrm{~m}\end{array}$ & $\begin{array}{l}\text { - } \mathrm{RC} \text { floor slab elements in } \\
1 \text { st, 5th, 10th and 15th (roof) } \\
\text { level. } \\
\text { - CLT in 3D modules }\end{array}$ \\
\hline & $60 \mathrm{~min}$ & $60 \mathrm{~min}$ & $\begin{array}{ll}\text { - } & 90 \text { min for primary } \\
\text { load-bearing elements } \\
60 \text { min for secondary } \\
\text { elements }\end{array}$ \\
\hline Building envelope U-values & $\begin{array}{l}U_{\text {roof }}=0.12 \mathrm{~W} / \mathrm{m}^{2} \mathrm{~K} \\
U_{\text {wall }}=0.16 \mathrm{~W} / \mathrm{m}^{2} \mathrm{~K} \\
U_{\text {floor }}=0.26 \mathrm{~W} / \mathrm{m}^{2} \mathrm{~K} \\
U_{\text {door } / \text { window }}=1.2 \mathrm{~W} / \mathrm{m}^{2} \mathrm{~K} \\
U_{\text {wall }}=0.16 \mathrm{~W} / \mathrm{m}^{2} \mathrm{~K} \\
U_{\text {floor }}=0.26 \mathrm{~W} / \mathrm{m}^{2} \mathrm{~K} \\
U_{\text {door/window }}=1.2 \mathrm{~W} / \mathrm{m}^{2} \mathrm{~K}\end{array}$ & No available data & $\begin{array}{l}U_{\text {roof }}<0.10 \mathrm{~W} / \mathrm{m}^{2} \mathrm{~K} \\
U_{\text {wall }}=0.12 \mathrm{~W} / \mathrm{m}^{2} \mathrm{~K} \\
U_{\text {floor }}=0.26 \mathrm{~W} / \mathrm{m}^{2} \mathrm{~K} \\
U_{\text {door/window }}=0.8 \mathrm{~W} / \mathrm{m}^{2} \mathrm{~K}\end{array}$ \\
\hline Active technical systems & $\begin{array}{l}\text { District heating — space and DHW } \\
\text { heating }\end{array}$ & $\begin{array}{l}\text { Heat recovery ventilation units in } \\
\text { each apartment, } \\
\text { geothermal heat pump }\end{array}$ & $\begin{array}{l}\text { Heat recovery ventilation units in } \\
\text { each apartment, } \\
\text { district heating-space and DHW } \\
\text { heating }\end{array}$ \\
\hline Energy class & $\begin{array}{c}Q_{h}=37 \mathrm{kWh} / \mathrm{m}^{2} \mathrm{a}(\text { measured } \\
\text { value in 2013) }\end{array}$ & CENED energy certificate, class A & Energy label A \\
\hline
\end{tabular}

* Via Cenni (for towers only).

\subsection{Limnologen Buildings (Växjö)}

Limnologen (Figure 3) designed by architectural office Arkitektbolaget Kronoberg was built in 2009 in Växjö, Sweden, a region dominated by large forests and wood-working sector companies [46]. The complex consists of four residential buildings with the first storey made of reinforced concrete, while seven storeys are made of timber. By the time it was erected, the Limnologen complex was the tallest timber building complex in Sweden. There are around 34 apartments with approximately 37 to $114 \mathrm{~m}^{2}$ in each of the four buildings. Apart from the residential spaces, there are also common facilities and a car park in the pertaining exterior areas.

The building shape is characterised by an asymmetrical lamella floor plan geometry with longer south-east and north-west façades equipped with extending balconies, giving all the apartments a direct view of Lake Trummen. The overhanging balconies also act as shading elements for lower positioned windows. All storeys have a similar floor plan with two central vertical communications cores, except the highest eighth storey, which has a smaller floor plan area partly covering the lower floor. The vertically repetitive floor plan is also reflected on the façades, which are not excessively structured in regard to the vertical pattern of windows. The buildings were designed with well insulated thermal envelope components having the U-values of $0.12 \mathrm{~W} / \mathrm{m}^{2} \mathrm{~K}$ for the roof, $0.16 \mathrm{~W} / \mathrm{m}^{2} \mathrm{~K}$ for walls, and $0.26 \mathrm{~W} / \mathrm{m}^{2} \mathrm{~K}$ for the floor, while the approximate U-value of windows is $1.2 \mathrm{~W} / \mathrm{m}^{2} \mathrm{~K}$. The buildings are equipped with a ventilation system and use district heating for heating spaces and domestic hot water (DHW). The calculated energy demand for 
space heating was $12 \mathrm{kWh} / \mathrm{m}^{2} \mathrm{a}, 35 \mathrm{kWh} / \mathrm{m}^{2}$ a for water heating, and $39 \mathrm{kWh} / \mathrm{m}^{2} \mathrm{a}$ for household electricity. The measured values showed higher consumption for the energy demand for heating, which amounted to $37 \mathrm{kWh} / \mathrm{m}^{2} \mathrm{a}$ in 2013. Although not reaching the passive house standard with regard to the climate of Växjö, the buildings can be rated as energy efficient. There are some data available on the environmental performance of the Limnologen buildings [46], but, due to the methodology of the environmental statement, they are not sufficient to make a comparison with other selected buildings.

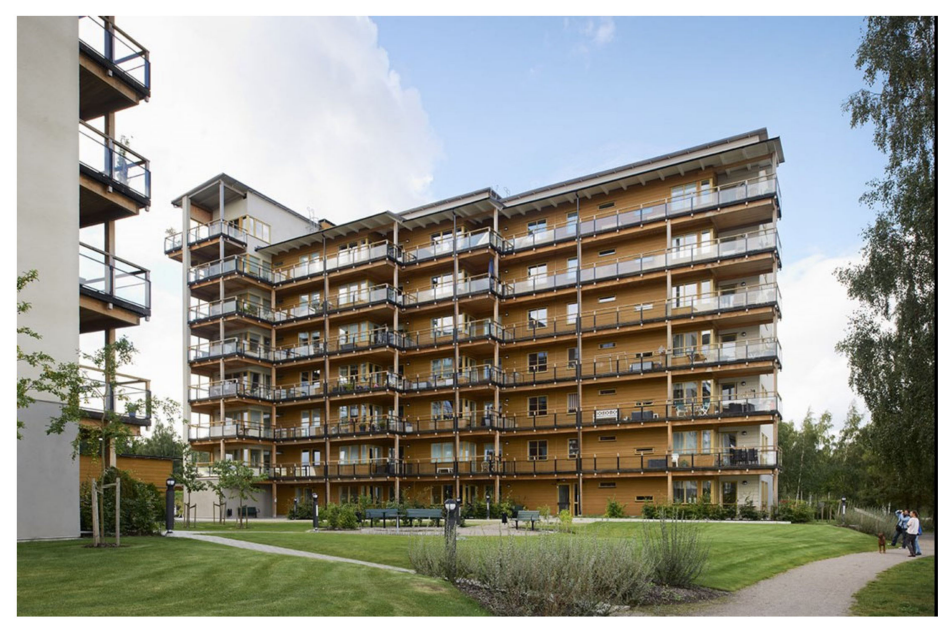

Figure 3. One of the four Limnologen buildings, Photograph by Åke E:son Lindman [47].

The Limnologen buildings (with seven storeys in timber only) are located in an area with a low seismic activity $\left(a_{g, 475}=0.02 \mathrm{~g}\right)$. Therefore, the basic wind load $\left(v_{b, 0}=25 \mathrm{~m} / \mathrm{s}\right)$ is decisive for determining the building racking resistance, but in comparison with Bergen, it is not extremely high. According to unofficial $[2,3]$ proposed classifications, the Limnologen buildings can be classified as mid-rise multi-storey timber buildings. Taking into account the horizontal load impact, the floor plan is not completely symmetric, which is why slight torsional effects acting primarily on the envelope wall elements can occur due to the horizontal load impact. Due to such torsional effects, stiffer CLT wall elements are chosen for envelope elements instead of less racking resistant timber-framed wall elements. They, however, have a lower U-value. Structurally, it is also important that storeys are equal in plane with the continuous support of all load-bearing wall elements, except the last storey partly covering the lower storeys.

With the building being mid-rise, the load-bearing structural system does not contain any additional reinforced concrete core to take over the horizontal load impact. As the CLT floor elements are strengthened with glue-laminated T-beams in the structural analysis, the decks are assumed to be acting as stiff horizontal plate diaphragms. Therefore, in view of the height of the building and a relatively low horizontal load impact caused by wind or earthquake, the racking resistance can be ensured only with a combination of prefabricated three-layer massive-panel CLT wall elements placed on the building envelope and prefabricated timber-framed wall elements separating the apartments. However, the first storey is built from reinforced concrete and takes over the maximal horizontal force impact that occurs in the first storey (see Figure 2). As the buildings are not extremely high, all load-bearing elements are designed to withstand fire for $60 \mathrm{~min}$.

\subsection{Via Cenni Social Housing (Milan)}

Europe's largest CLT residential complex designed by architectural office Rossiprodi Associati is the Via Cenni Social Housing in Milan (Figure 4). The complex constructed in 2013 forms a dynamic flow of public and semi-public open space, which encourages integration between various services and functions, and between the community and the district [48]. The built tissue is divided into four similar timber towers connected by 
several two-storey linear buildings, both built on the top of a concrete basement and an underground car park.

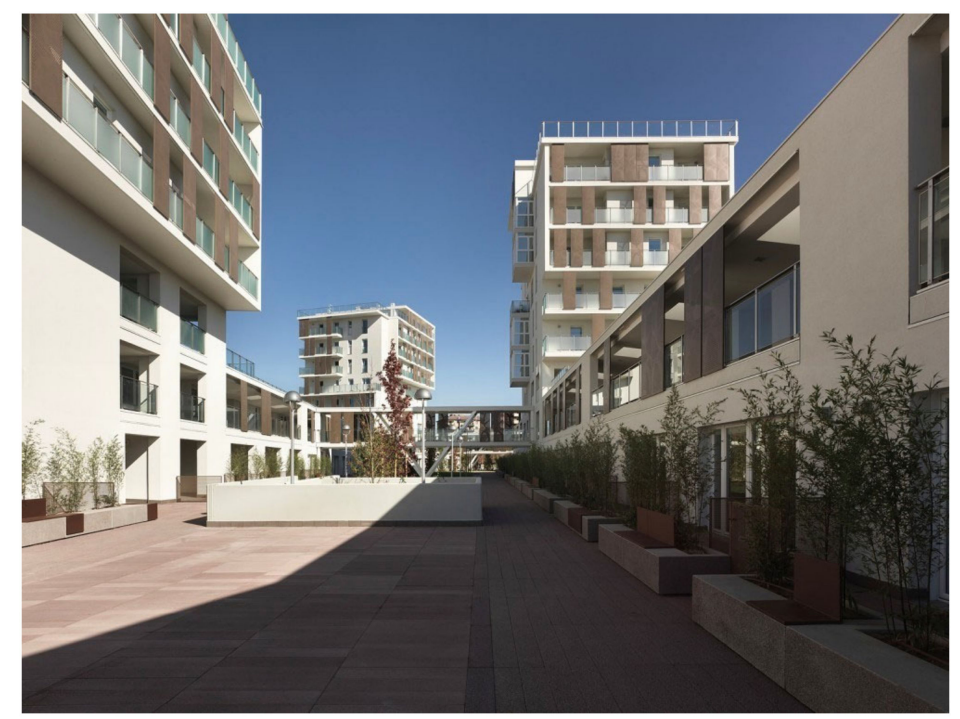

Figure 4. Via Cenni social housing complex in Milan, Photograph by Pietro Savorelli [49].

The maximum height of the timber towers is 27 metres with nine storeys above the ground line. Therefore, they can be classified as high-rise timber buildings according to [1,2]. In contrast, if the classification from [3] is taken into account, they could be included into a group of mid-rise timber buildings, since the number of timber storeys is lower than ten. In addition to the built tissue with 124 apartments with approximately 50 to $100 \mathrm{~m}^{2}$, urban service, social, common, and multipurpose spaces, the Via Cenni residential area includes carefully designed open and green public areas intended for socialising and recreation [50]. The rich conglomerate of built and open spaces points towards the main idea of the project having the character of an open contemporary city [51]. From the aspect of architectural expression, a mix of built and open spaces reflects the vivid design composition. The floor plan geometry of timber towers is relatively symmetrical with 3-4 apartment units spread around the centrally positioned structural core with the exception of balconies and loggias asymmetrically alternating on the façade plane. Regarding the vertical floor plan symmetry, floor plans vary slightly according to the disposition of rooms, while the main load-bearing walls are continuous, not interrupted, on the same structural axis on all floors. As previously mentioned, the façade openings and positions of balconies vary slightly on different floors but have no major influence on the regularity of the main structure. The floor plan of nine-storey towers is rectangular with dimensions of $13.6 \times 19.1 \mathrm{~m}$.

There are no available data on the thermal envelope components U-value design. However, the thermal properties of cross-laminated timber and the relatively compact design of building volumes may be among the reasons the complex reaches the low energy efficiency standard CENED class A [51]. The space heating energy is provided with a geothermal heat pump, while all the apartments have their own heat recovery ventilation unit.

As the building is located in a moderately active seismic area with $a_{g, 475}=1.201 \mathrm{~m} / \mathrm{s}^{2}$ $=0.122 \mathrm{~g}$, it can be recognised as the first high-rise full CLT timber building located in an active seismic area. It is also important to point out that the building height/width ratio $\left(H / L_{\text {omax }}=1.414\right)$ is quite high, so the building structurally behaves as a "stand alone timber construction" with a similar technology to the towers. In comparison with Växjö, it can be concluded that the seismic load impact is essentially higher, but the basic wind load $\left(v_{b, 0}=25 \mathrm{~m} / \mathrm{s}\right)$ is equal.

It is specific for the nine-storey Via Cenni building that the load-bearing vertical and horizontal structural system consists completely of prefabricated massive-panel CLT 
elements used for all floor and resisting load-bearing wall elements. Similar to the Limnologen building, there is no structural need for an additional load-bearing concrete core to ensure the horizontal stability of the structure. Like in the Limnologen building in the structural analysis, the five-layer and seven-layer CLT decks are assumed to be acting as stiff horizontal plate diaphragms. However, the thickness of the CLT floor elements depends on the deck span. It is $200 \mathrm{~mm}$ for spans shorter than $5.80 \mathrm{~m}$ and $230 \mathrm{~mm}$ for spans between 5.80 and $6.70 \mathrm{~m}$. Compared to the Limnologen building and Via Cenni, there is no additional strengthening of the CLT floor elements with glue-laminated T-beams, and the total deck thickness is not constant but depends on its span. Since the horizontal load impact in terms of bending moments and shear forces decreases with the $\mathrm{z}$-coordinate (see schematical presentation in Figure 2), the thickness of five-layer CLT wall elements is not constant along the height of the building and is minimal on the ninth storey $(120 \mathrm{~mm})$ and maximal on the first storey $(200 \mathrm{~mm})$. Respecting the Italian standards, the fire resistance of $60 \mathrm{~min}$ for all load-bearing wall and floor elements is prescribed, which is similar to the previously analysed Limnologen building, which is of a very similar height.

\subsection{Treet (Bergen)}

The 14-storey timber tower apartment building Treet ("tree" in Norwegian) designed by architectural office Artec shown in Figure 5, whose glulam truss structure draws its inspiration from contemporary bridge design, was completed in 2015 in Bergen, Norway [48] and was recognised as the tallest timber building of that time.

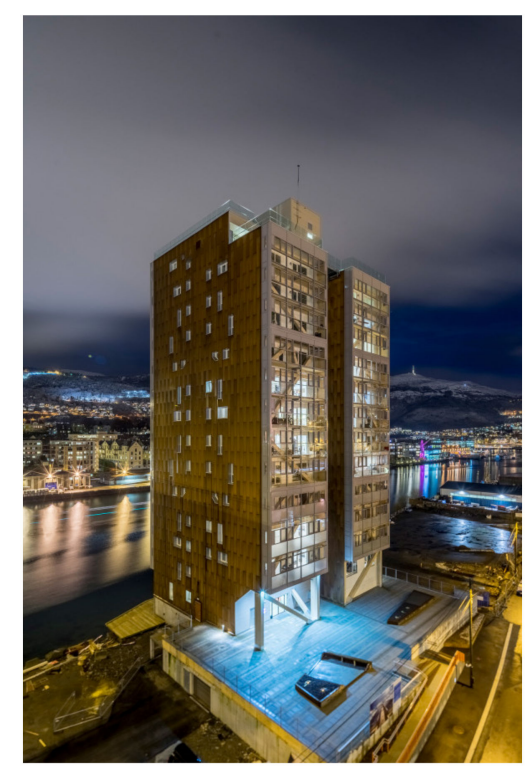

Figure 5. Treet-timber tower apartment building in Bergen, Photograph by David Valideby [52].

With its height of 52.8 metres, it is a high-rise timber building according to all classifications [1-3]. The building stands on a garage reinforced-concrete podium. The maximum vertical distance between the lowest and highest points of timber components is $49 \mathrm{~m}$. The concept of the Treet building is analogous to that of a cabinet rack filled with drawers, in which the sides and shelves of the rack are formed by large glulam trusses, and the drawers consist of prefabricated residential modules [48]. The building with 62 apartments ranging from 43 to $66 \mathrm{~m}^{2}$ in size has a compact shape. The floor plan geometry is rectangular, measuring approximately $21 \times 23 \mathrm{~m}$, with four to five apartments spread around the main central structural CLT core, which is independent from the main structure. There is an additional staircase core for the case of fire. From the perspective of vertical geometry, the building shows symmetry in terms of modular dimensions, while the floor plans slightly vary in different storeys, but only within the modular limits. Therefore, the alternation of floor plans has no major influence on the regularity of the main structure. The north 
and south façades are designed as fully glazed with balconies. Originally, the building was planned with timber cladding on the east and west side. Since it was not possible to find any fire treatment, which was durable for more than five years (an impossible frequency considering maintenance costs), these façades are in metal cladding [53]. The glulam trusses as part of the main load-bearing structure embrace the building and are visible in the north and south glazed façades. The enclosing glass and metal cladding façades protect the timber trusses from moisture and ultraviolet degradation and permit the glulam to be specified for interior rather than exterior use [48].

All exposed timber elements are fire-retardant treated. The building is designed with well insulated thermal envelope components having the U-values $0.12 \mathrm{~W} / \mathrm{m}^{2} \mathrm{~K}$ for the walls, $0.26 \mathrm{~W} / \mathrm{m}^{2} \mathrm{~K}$ for the floor, and less than $0.10 \mathrm{~W} / \mathrm{m}^{2} \mathrm{~K}$ for the roof, while the approximate U-value of windows is $0.8 \mathrm{~W} / \mathrm{m}^{2} \mathrm{~K}$. The apartments are equipped with a heat recovery ventilation system and use district heating for heating spaces and DHW. The calculated energy demand for space heating is only $3 \mathrm{kWh} / \mathrm{m}^{2}$ a plus $4.5 \mathrm{kWh} / \mathrm{m}^{2}$ a for ventilation heating, the $29.8 \mathrm{kWh} / \mathrm{m}^{2}$ a for water heating, $11.4 \mathrm{kWh} / \mathrm{m}^{2} \mathrm{a}$ for lighting, and $22.4 \mathrm{kWh} / \mathrm{m}^{2}$ a for household electricity, which includes household appliances, technical equipment, and pump and fan administration. The building carries energy label $\mathrm{A}$. The only available data related to environmental performance is that the building stores 2000 tons of $\mathrm{CO}_{2}$. It is important to mention that the fire-retardant treatment (of the exposed timber) contains various chemicals that are not good for the environment [53].

The building structure is very complex, combining multiple components, such as timber CLT modules, framework in laminated timber (a supporting structure with powerfloor), vertical building elements in CLT, concrete platforms as bases for the next set of floors with modules, a roof construction with terraces, balconies (the balcony floor and a supporting structure for glass façades), and façades.

Prefabricated 3D CLT building modules constitute the main volume of the building. The modules are stacked together at a maximum of four storeys, where the concrete slabs are placed. The modules are designed in the passive energy standard. Since each module has its own floor, wall, and ceiling assemblies, there are two layers of construction both horizontally and vertically between units, and the modules are assembled on site. This arrangement meets the required acoustic standards without any additional measures being necessary [48].

There is also a massive timber core made of CLT placed practically in the middle of the floor plane and used for stairs and elevators only. It is specific for this building that it is erected in a heavily windy but not really active seismic area. The building is designed for a maximal wind velocity of $v_{m}=44.8 \mathrm{~m} / \mathrm{s}$ with the maximal wind load at the top of the building of $q_{p}=1.254 \mathrm{kN} / \mathrm{m}^{2}$. The maximal designed seismic ground acceleration with a 475 -year return time period is $a_{g, 475}=0.9 \mathrm{~m} / \mathrm{s}^{2}=0.092 \cdot \mathrm{g}$ and can therefore be recognised as a "low seismic" hazard. Consequently, the seismic design can be omitted according to the Norwegian code, and the wind load prevails according to Figure 2.

The gravity loads system of each level is composed of CLT floors that locally support the residential prefabricated 3D timber modules [3]. Levels 5 and 10 are s.c. "power storeys" made of reinforced concrete slabs [54]. The concrete slabs also act as a supporting base for the next four levels of the stacked prefabricated CLT modules. However, their main functions are primarily to increase the building's mass and improve the dynamic behaviour caused by a heavy wind load.

The lateral structural system is formed by a truss net of glue-laminated diagonals, studs, and beam elements, while the reinforced-concrete slabs on levels 5 and 10, and on the roof, are incorporated to connect the timber trusses together in each of the four storeys. It is important to point out that the CLT walls of the building core are independent of the main truss load-bearing lateral structural system and do not significantly contribute to the horizontal stiffness of the building. Therefore, there is no hybrid combination of different lateral load-bearing timber structural systems like in the case of the previously analysed Limnologen building. 
Globally, from the structural point of view, this fully timber building is very high with the first natural frequencies of 0.75 (east-west) and $0.89 \mathrm{~Hz}$ (north-south). Therefore, the horizontal load impact (wind in this case) can be very problematic. For this reason, it is of the utmost importance that the floor plan is very simple in form and practically symmetric, even if the building is not subjected to the decisive seismic load. There is also no important change in the horizontal stiffness of the building between the storeys. Consequently, according to the Eurocode 8 [36] prescribed rules, the building can be classified as regular in floor plan and height. Because of a considerable height of the building, fire resistance is also very problematic. Consequently, all prefabricated CLT modules and all load-bearing truss timber elements are designed for $90 \mathrm{~min}$ fire resistance.

\section{Discussion}

The analysed multi-storey timber buildings were built in different time periods, i.e., the Limnologen complex in 2009, the Via Cenni social housing in 2013, and the Treet building in 2015. It can be claimed that the age of the buildings is reflected in their architectural expression. Firstly, if the chronological aspect is considered, the height of the buildings increases with the year of construction. Secondly, the geometry and façade expression differ significantly. Limnologen has moderately glazed and relatively symmetrical façades. A much more dynamic arrangement of façade openings and loggias is characteristic for Via Cenni, while the Treet building has fully glazed north and east façades. The latter corresponds to the findings from [2], where a shift away from opaque external walls with punched openings towards partially or completely glazed technologies in new generations of MSTB was noticed. It is also evident that the floor plan geometry in both higher buildings, Via Cenni and Treet, is more symmetrical within the frames of vertical extension. Although there is a slight variation of floor plans, it is only present within the main load-bearing axes, which are repetitive in all the storeys.

From the perspective of energy efficiency, not only the time of construction but also the climate has a strong impact. Although located in similar climatic areas, the Treet building has slightly lower U-values of the building envelope if compared to Limnologen. The energy statement of both buildings, however, differs more significantly. The energy demand for heating is much higher in the older Limnologen complex, which is a consequence of the building design with a less compact form and less favourable orientation. Whereas there is no available accurate data on the building envelope of the Via Cenni housing, it can be assumed that the $\mathrm{U}$-values are close to the passive standard, since the final energy statement carries energy certificate class A.

It is evident from the presented data that some timber material properties, especially the modules of elasticity, strongly influence the height and the floor shape of high-rise timber buildings. This influence and the limitations rapidly increase with the height of a building and consequently with more considerable horizontal load impact (wind, earthquake) on that building, as schematically presented in Figure 2. Both horizontal load actions primarily depend on the given local climate conditions.

For example, the analysed Treet building in Bergen, as the highest selected building, is not dimensioned for earthquakes, because the seismic load produces evidently lower horizontal forces than the wind action. Additionally, even considering only the wind load impact as decisive, the building floor plan is very compact and rectangular without any special forms. It can be predicted that such a 14-storey high timber building cannot be constructed in more seismically active areas or can be able to resist the seismic load impact only by using additional special concrete cores.

It is also interesting to compare the structural design concepts of the Limnologen building with Via Cenni. Both buildings are subjected to equal reference basic wind velocity $\left(v_{b, 0}=25 \mathrm{~m} / \mathrm{s}\right)$, and the height of the buildings is very similar. However, the Limnologen building in Bergen is located in an area with a low seismic activity with ground design acceleration only $a_{g, 475}=0.20 \mathrm{~m} / \mathrm{s}^{2}$. On the other hand, Via Cenni in Milan stands in a moderately active seismic area with essentially higher ground design 
acceleration $a_{g, 475}=1.201 \mathrm{~m} / \mathrm{s}^{2}$. The seismic load impact is therefore decisive, as the horizontal load impact for Via Cenni, but not for Limnologen. Consequently, although the height of both analysed buildings is very similar, the floor plan form of Limnologen is much more unsymmetric and produces slight torsional actions, particularly on envelope wall elements in comparison with Via Cenni. Therefore, a hybrid timber structural system is used, combining more resisting CLT wall elements on the building envelope and less stiff timber-framed elements for internal walls. On the other hand, because of a relatively high seismic impact, the Via Cenni building is constructed only with CLT load-bearing wall elements with an almost symmetric floor plan design to avoid any torsional effects caused by the seismic load.

\section{Conclusions}

In the early 21st century, there has been a marked increase in the number of multistorey timber buildings. However, considering the large forest cover and the well-developed prefabricated timber building industry in many European countries, the potential of multistorey timber construction remains partially unexploited. To explore its potential, the current paper reviews the advantages, problems, and the state of such construction in Europe. The second part of the paper includes a detailed analysis of three selected case studies, i.e., the Limnologen complex, the Via Cenni social housing, and the Treet building, which are constructed only in pure timber structural systems meeting the load-bearing structural requirements and ensuring a low ecological impact caused by solely timber elements. From the time perspective, the shift in the architectural design, especially that of façades, the lowering of thermal transmittance coefficient of the thermal envelope, and also the shift from massive panel to hybrid structural system are evident. There are also apparent differences in the structural end energy efficiency design deepened on the location and its seismic and climatic characteristics. The comparison of the selected buildings architectural, energy, and structural design features exposes their main design adjustments to the local geographical and time context.

The current paper's contribution to science is in the presentation of important features of multi-storey timber buildings, which must be discussed by architects, structural engineers, and other actors involved in the construction sector to select suitable solutions in the early stage of design with a long-term goal to produce more optimised and cost-effective methods of multi-storey timber construction to be used in daily practice. Demonstrating more extensive knowledge on the design of multi-storey timber buildings, the findings of the paper can make a significant contribution to fostering the potential of timber construction in Europe and the rest of the world.

Author Contributions: "Both authors contributed equally to the paper". Conceptualisation, V.Ž.L. and M.P, methodology, V.Ž.L. and M.P; validation, V.Ž.L. and M.P.; formal analysis, V.Ž.L. and M.P.; investigation, V.Ž.L. and M.P.; resources, V.Ž.L. and M.P.; writing—original draft preparation, V.Ž.L. and M.P.; writing—review and editing, V.Ž.L. and M.P.; visualization, V.Ž.L. and M.P.; funding acquisition, V.Ž.L. and M.P. All authors have read and agreed to the published version of the manuscript.

Funding: "This research received no external funding" or "This research was funded by the Slovenian Research Agency and the Ministry of Higher Education, Science and Technology of the Republic of Slovenia, National research programme P2-0129".

Data Availability Statement: Permissions for Figures 3-5 provided by Authors.

Conflicts of Interest: "The authors declare no conflict of interest." "The funders had no role in the design of the study; in the collection, analyses, or interpretation of data; in the writing of the manuscript; or in the decision to publish the results". 


\section{References}

1. Technical Design Guide. Mid-rise Timber Buildings, Class 2, 3 and 5 Buildings. Issued by FWPA. 2017. Available online: https:/ / www.woodsolutions.com.au/articles/mid-rise-timber-buildings-design-guides (accessed on 12 January 2021).

2. Kuzmanovska, I.; Gasparri, E.; Tapias Monné, D.; Aitchison, M. Tall Timber Buildings: Emerging trends and typologies. In Proceedings of the 2018 World Conference on Timber Engineering, Seoul, Korea, 20-23 August 2018.

3. Salvadori, V. The Development of a Tall Wood Building. Master's Thesis, Politecnico Milano, Milan, Italy, TU Wien, Vienna, Austria, 2017.

4. Žigart, M.; Kovačič Lukman, R.; Premrov, M.; Žegarac Leskovar, V. Environmental impact assessment of building envelope components for low-rise buildings. Energy 2018, 163, 501-512. [CrossRef]

5. Kuzman, M.; Sandberg, D. A new era for multi-storey timber buildings in Europe. In Proceedings of the New Horizons for the Forest Products Industry: 70th Forest Products Society International Convention, Portland, OR, USA, 26-29 June 2016; Forest Products Society: Madison, WI, USA, 2016; p. 7.

6. Li, J.; Rismanchi, B.; Ngo, T. Feasibility study to estimate the environmental benefits of utilising timber to construct high-rise buildings in Australia. Build. Environ. 2019, 147, 108-120. [CrossRef]

7. Žegarac, L.V.; Premrov, M. Timber-Glass Prefabricated Buildings. In Energy-Efficient Timber-Glass Houses; Springer: London, UK, 2013; pp. 117-178.

8. Follesa, M.; Fragiacomo, M.; Casagrande, D.; Tomasi, R.; Piazza, M.; Vassallo, D.; Canetti, D.; Rossi, S. The New Provisions for the Seismic Design of Timber Buildings in Europe. Eng. Struct. 2018, 168, 736-747. [CrossRef]

9. Barber, D. Determination of fire resistance ratings for glulam connectors within US high rise timber buildings. Fire Saf. J. 2017, 91, 579-585. [CrossRef]

10. Östman, B.; Brandon, D.; Frantzich, H. Fire safety engineering in timber buildings. Fire Saf. J. 2017, 91, 11-20. [CrossRef]

11. Östman, B.; Jarnerö, K.; Sjökvist, L.; Larsson, K.; Tillberg, K. Acoustics in Wooden Buildings. State of the Art 2008 summary of a Swedish cooperation project. In Proceedings of the Joint Baltic-Nordic Acoustics Meeting 2008, Reykjavik, Iceland, 17-19 August 2008; SP Technical Research Institute of Sweden, Box: Borås, Sweden, 2008.

12. Östman, B.; Källsner, B. National Building Regulations in Relation to Multi-Storey Wooden Buildings in Europe; SP Trätek and Växjö University: Växjö, Sweden.

13. Goubran, S.; Masson, T.; Walker, T. Diagnosing the local suitability of high-rise timber construction. Build. Res. Inf. 2020, 48, 101-123. [CrossRef]

14. Kaufmann, H.; Krötsch, S.; Winter, S. Manual of Multistorey Timber Construction, Edition Detail. Cohesion Policy Beyond 2020. Available online: https: / /www.eu-skladi.si/sl/po-2020 (accessed on 13 January 2021).

15. Marsh, J. Tokyo to Build World's Tallest Timber Tower. CNN. Available online: https://www.cnn.com/style/article/woodenskyscrapers-timber-trend-catchingfire-duplicate-2/index.html (accessed on 15 January 2021).

16. Mills, F. Top 5: The World's Tallest Timber Buildings. The B1M. Available online: https://www.theb1m.com/video/top-5-theworld-s-tallest-timber-buildings (accessed on 13 January 2021).

17. Smith, I.; Frangi, A. Structural Engineering Documents 13, Use of Timber in Tall Multi-Storey Buildings, International Association for Bridge and Structural Engineering (IABSE); ETH Zürich: Zürich, Switzerland, 2014.

18. United Nations. World Population Prospects-the 2017 Revision: Key Findings and Advance Tables; Department of economic and social affairs population division: New York, NY, USA, 2017; pp. 1-46.

19. Bruno, R.; Bevilacqua, P.; Cuconati, T.; Arcuri, N. Energy evaluations of an innovative multi-storey wooden near Zero Energy Building designed for Mediterranean areas. Appl. Energy 2019, 238, 929-941. [CrossRef]

20. Demirci, C.; Málaga-Chuquitaype, C.; Macorini, L. Seismic shear and acceleration demands in multi-storey cross-laminated timber buildings. Eng. Struct. 2019, 198. [CrossRef]

21. Ferdous, W.; Bai, Y.; Ngo, T.D.; Manalo, A.; Mendis, P. New advancements, challenges and opportunities of multi-storey modular buildings-A state-of-the-art review. Eng. Struct. 2019, 183, 883-893. [CrossRef]

22. Skullestad, J.L.; Bohne, R.A.; Lohne, J. High-rise Timber Buildings as a Climate Change Mitigation Measure-A Comparative LCA of Structural System Alternatives. Energy Procedia 2016, 96, 112-123. [CrossRef]

23. Sposito, C.; Scalisi, F. High-rise timber architecture: An opportunity for the sustainability of the built environment. In ProInnovation: Process Production Product; Palermo University Press: Palermo, Italy, 2019; Volume 02, pp. $93-122$.

24. Vogrinec, K.; Premrov, M. Influence of the design approach on the behaviour of timber-frame panel buildings under horizontal forces. Eng. Struct. 2018, 175, 1-12. [CrossRef]

25. Waugh, A.; Weiss, K.H.; Wells, M. Process Revealed Auf dem Holzweg; Murray \& Sorrell FUEL: London, UK, 2009.

26. Abrahamsen, R.B. The world's tallest timber building. In Proceedings of the Tallinn Wood Architecture Conference, Sweco, Lillehammer, Norway, November 2014.

27. Dodoo, A.; Gustavsson, L. Energy use and overheating risk of Swedish multi-storey residential buildings under different climate scenarios. Energy 2016, 97, 534-548. [CrossRef]

28. Takano, A.; Pal, S.K.; Kuittinen, M.; Alanne, K. Life cycle energy balance of residential buildings: A case study on hypothetical building models in Finland. Energy Build. 2015, 105, 154-164. [CrossRef]

29. Treloar, G.; Fay, R.; Ilozor, B.; Love, P.E.D. An analysis of the embodied energy of office buildings by height. Facilities 2001, 19, 204-214. [CrossRef] 
30. Foraboschi, P.; Mercanzin, M.; Trabucco, D. Sustainable structural design of tall buildings based on embodied energy. Energy Build. 2014, 68, 254-269. [CrossRef]

31. Guo, H.; Liu, Y.; Meng, Y.; Huang, H.; Sun, C.; Shao, Y. A Comparison of the Energy Saving and Carbon Reduction Performance between Reinforced Concrete and Cross-Laminated Timber Structures in Residential Buildings in the Severe Cold Region of China. Sustainability 2017, 9, 1426. [CrossRef]

32. Leskovar, V.Ž.; Žigart, M.; Premrov, M.; Lukman, R.K. Comparative assessment of shape related cross-laminated timber building typologies focusing on environmental performance. J. Clean. Prod. 2019, 216, 482-494. [CrossRef]

33. Tall Timber: A Global Audit. Available online: https://waughthistleton.com/media/press/17060_Tall_buildings_in_ numbersCTBUH.pdf (accessed on 16 January 2021).

34. Abrahamsen, R.B.; Malo, K.E. Structural design and assembly of "Treet"-A 14-storey timber residential building in Norway. In Proceedings of the WCTE 2010 Conference on Timber Engineering, Quebec, QC, Canada, 10-14 August 2014.

35. Woschitz, R.; Zotter, J. High-rise Timber Building HoHo Vienna-The structural Concept. Österr. Ing. Archit. Z. 2017, 162, 1-6.

36. European Committee for Standardization. EN 1998-1 Eurocode 8: Design of structures for earthquake resistance, In Part 1: General Rules, Seismic Actions and Rules for Buildings; European Committee for Standardization: Brussels, Belgium, 2005.

37. European Committee for Standardization CEN/TC 250/SC5 N173. EN 1995-1-1: 2005 Eurocode 5: Design of timber structures, In Part 1-1 General Rules and Rules for Buildings; European Committee for Standardization: Brussels, Belgium, 2005.

38. Blyberg, L.; Serrano, E.; Enquist, B.; Sterley, M. Adhesive joints for structural timber/glass applications: Experimental testing and evaluation methods. Int. J. Adhes. Adhes. 2012, 35, 76-87. [CrossRef]

39. Hochhauser, W. A Contribution to the Calculation and Sizing of Glued and Embedded Timber-Glass Composite Panes. Ph.D. Thesis, Faculty of Civil Engineering, Vienna University of Technology, Vienna, Austria, 2011.

40. Premrov, M.; Serrano, E.; Winter, W.; Fadai, A.; Nicklisch, F.; Dujič, B.; Šušteršič, I.; Brank, B.; Štrukelj, A.; Držečnik, M.; et al. Testing on life-size specimen components: Shear walls, beams and columns including long-term behaviour. In Proceedings of the Woodwisdom-Net, Research Project, Load-Bearing Timber-Glass-Composites, Helsinki, Finland, 7-8 February 2012; Workshop Report WP 6.

41. Premrov, M.; Žegarac Leskovar, V.; Kozem Šilih, E.; Ber, B.; Lešnik, M.; Kolarič Tibaut, N.; Maučec, D. Development of multifunctional climate active load-bearing envelope of buildings-HOME+. In Transportation Engineering and Architecture; Final Report of Activity TRL 3-4; University of Maribor, Faculty of Civil Engineering: Maribor, Slovenia, 2020.

42. Premrov, M.; Žegarac Leskovar, V.; Kozem Šilih, E.; Ber, B. Development of Load-Bearing Façade Prefabricated Wall Element with Double Glazing. Patent application No. P-202000185, 13 October 2020.

43. Hamburg, P.; Lellep, K.; Kiisa, M. Sustainable High-Rise Buildings Designed and Constructed in Timber (HiTimber), International Study on Best Practices and Knowledge Gaps for Construction of High-Rise Timber Buildings; TTK University of Applied Sciences: Tallin, Estonia, 2018.

44. Kolb, J. Systems in Timber Engineering; Birkhäuser Verlag AG: Basel, Switzerland, 2008.

45. European Committee for Standardization CEN/TC 250/SC5 N173. EN 1991-1-4: Eurocode 1-Part 4: Actions on structures, In Part 1-4: General Actions-Wind Actions; European Committee for Standardization: Brussels, Belgium, 2005.

46. Serrano, E. Overview and Summaries of Sub Projects Results, Documentation of the Limnologen Project; Reports No. 56; School Technology and Design, Växjö University: Växjö, Sweden, 2009.

47. Limnologen. Available online: https://arkitektbolaget.se/projekt/limnologen/ (accessed on 30 November 2020).

48. Green, M.; Taggart, J. Tall Wood Buildings Design, Construction and Performance; Birkhaäuser Verlag GmbH: Basel, Switzerland, 2017.

49. Social Housing Via Cenni. Available online: http://www.rossiprodi.it/?project=social-housing-via-cenni-2 (accessed on 30 November 2020).

50. Bernasconi, A. Timber construction in the city of Milan, \$ residential buildings with 9 storeys. In Proceedings of the European Wood Network Meeting 2012, Milan, Italy, 7 June 2012; European Network for Wood Science and Engineering: Hanover, Germany, 2012.

51. Rossiprodi Associati. Residential and Commercial District in Milan, Social Housing Via Cenni, 2012. Available online: https: / /issuu.com/genise/docs/cenni_eng_de22a73f337c4a (accessed on 8 February 2021).

52. “Treet" Residential High-Rise, Bergen. Available online: https:/ / artec.no/prosjekter/treet/ (accessed on 30 November 2020).

53. Trifkovič, M. Treet-World's Tallest Timber Building. Artec. Wood Works, Program of the Canadian Wood Council. Available online: https:// wood-works.ca/wp-content/uploads/TREET-The-Worlds-Tallest-Timber-Building-Trifkovic.pdf (accessed on 8 February 2021).

54. Abrahamsen, R.B. World's tallest timber building-14 storeys in Bergen. In Proceedings of the Internationales Holzbau-Forum IHF, Garmisch-Partenkirchen, Garmisch-Partenkirchen, Germany, 2-4 December 2015. 